\title{
The Role of Vermicompost and Foliar Spray of Spirulina Platensis Extract on Vegetative Growth, Yield and Nutrition Status of Lettuce Plant under sandy soil
}

\author{
Yassen, A.A, Entsar M. Essa and Sahar M. Zaghloul \\ Plant Nutrition Department, National Research Centre, .33 El- Behooth St. P.O. 12622. Dokki, Cairo, Egypt \\ Correspondence Author: Yassen AA, Plant Nutrition Department, National Research Centre, .33 El- Behooth St. P.0. 12622. Dokki, \\ Cairo, Egypt \\ E-mail: khaledrheem75@gmail.com
}

Received date: 14 April 2019, Accepted date: 28 June 2019, Online, Online date: 12 July 2019

Copyright: (C) 2019Yassen AA et al., This is an open-access article distributed under the terms of the Creative Commons Attribution License, which permits unrestricted use, distribution, and reproduction in any medium, provided the original author and source are credited.

\begin{abstract}
A field experiment was conducted during successive seasons at the experimental station of the National Research Centre in Nubaria region, Egypt to assess the effects of vermicompost and foliar spray of Spirulina platensis extract on vegetative growth, yield and nutrition status of lettuce plant.Results indicated that addition of vermicompost fertilizer at rates of $\left(1,2\right.$ and 3 ton fed $\left.^{-1}\right)$, and foliar spray of spirulina platensis extract (1and $2 \mathrm{gL}^{-1}$ ) within all tested treatments resulted had significant increases promoted growth characters, yieldand chemical composition (N, P, K, Fe, $\mathrm{Zn}, \mathrm{Mn}, \mathrm{Cu}$, and vitamin $\mathrm{C}$ ) in leaves and roots as compared to the control treatment.The highest valueapplication ofvermicompost at 2 ton $\mathrm{fed}^{-1}+$ foliar spray of spirulina platensis extract $2 \mathrm{gL}^{-1}$ in most growth characters plant height, fresh and dry matter of leaves, number of leaves,fresh and dry matter of rootsg andleaf area) and yield.In addition, data showed that decreasing vermicompost fertilizer and foliar spray of spirulina platensis extract reducedtotal carbohydrate content \%in leaves.
\end{abstract}

Keywords: Vermicompost, Spirulina platensis extract, yield, chemical composition, lettuce

\section{INTRODUCTION}

Lettuce (Lactuca sativa L.) is easy to grow and its growth period is short and the economic benefit is higher. In Egypt lettuce are cultivated for local consumption and export. The head and leaves are rich in several minerals, vitamins and essential source of antioxidants [1]. It also possesses various health benefits such as anti-inflammatory properties, protects neuronal cells, lowers risk of cancer and heart diseases, prevents tiredness and often prescribed to weight-conscious consumers because of its low calories content. 
The deficiency of soil nutrients in sandy soil is now regarded as one of the significant limitations for production vegetable in the world. The use of organic farming eliminates or decreases the indiscriminate use of chemical fertilizers that affect groundwater, air pollution, and minimizes the impact of a salt accumulation from the extensive and continuous use of chemical fertilizers that increase environmental production cost [2]. In lettuce crops, organic farming can play a vital role in reducing the amount of toxic compounds (such as nitrates), hence, improving the quality of leaves, maximizing the production and profitability [3].

Irajkhazaei et al., [4] found that organic fertilizer-grown leafy vegetables such as spinach, lettuce, chard, savoy cabbage and white cabbage grew better and resulted in a greater complete yield and mineral content than a chemical fertilizer-grown vegetable. Hossain and Ryu [5] found that application of organic fertilizer significantly increases leaf size, fresh weight, dry weight, N, P, K, $\mathrm{Ca}, \mathrm{Mg}$ and $\mathrm{Na}$ uptake of lettuce plants over chemical fertilizers.Currently, the use of organic manures and biofertilizers such as vermicompost and algae has resulted to a reduction in the use of chemical fertilizers and to the provision of high-quality products free of damaging agrochemicals for human safety [6]. Vermicomposts are the product of the mesophyllic biodegradation and stabilization of organic materials through the interactive actions of microbes and earthworms. This product is rich in organic compounds, microbial life, mineral nutrients, phytohormones and humic acids. Thus improving their suitability for agricultural practices [7].

Biofertilizers are organic products containing live or latent cells of different types of microorganisms (bacterial, fungal or algal) The main advantages of biofertilizers are: cheap nutrient sources; suppliers of microelements; suppliers of organic matter; counteracting the negative effects of chemical fertilizers; secretion of growth hormones; no adverse effects to ecosystem and longer shelf life [8]. Spirulina platensis is a rich source of mineral nutrient, which hence stimulate root establishment, root elongation and promote vegetative growth of plants [9].

Foliar application of algae extract induce many positive effects, where spraying plants had led to improve crop yield and quality, increase nutrient uptake, resistance to frost and stress conditions especially those grown under semi-arid and desert condition [10]. Faheed and Fattah [11] found that the application of Chlorella Vulgaris was also found to be beneficial to the growth of lettuce (Lactuca sativa). Also, Shy et al., [12] indicated that arugula plants cultivated in soil enriched with Spirulina shown that increased plant height, chlorophyll content, fresh and dry weights When compared to the control(chemical fertilizers).

The paper aimed to study the effects of vermicompost and spirulina algae on growth, yield and nutritional state of lettuce plants grown on sandy soil.

\section{MATERIALS AND METHODS}

A field experiment was carried out during the two successive seasons of 2017 and 2018 at the experimental station of the National Research Centre in Nubaria region, Egypt to study the effect different rates of vermicompost and foliar spray of Spirulina platensis extract on vegetative growth, yield and nutrition status of lettuce plants. Prior to any practices, a composite soil sample was taken from the soil surface $(0-30 \mathrm{~cm})$ of the experimental site, air- dried, sieved by $2 \mathrm{~mm}$ sieve and analyzed. The physical and chemical properties of soil were determined according to Klute [13] and [14]. The experimental soil was sandy in texture and chemical properties were: $\mathrm{pH}=7.70, \mathrm{EC}=0.54 \mathrm{dSm}^{-1}$ at $25^{\circ} \mathrm{C}$, Organic matter $=0.12 \%, \mathrm{~N}=22.4 \mathrm{mg} \mathrm{kg}^{-1}, \mathrm{P}=3.40 \mathrm{mg} \mathrm{kg}{ }^{-1}, \mathrm{~K}^{2}=$ $60.2 \mathrm{mg} \mathrm{kg}^{-1}$.Seedlings were transplanted when two leaves were completely expanded 30days after sowing Seeds of lettuce (lactuca sativa L.) cv. Batavia. Seedlings were set up in the field on $20^{\text {th }}$ of October and $15^{\text {th }}$ of November in the first and second seasons, respectively. Seedlings were planted on one side of ridges $25 \mathrm{~cm}$ apart, ridges were $80 \mathrm{~cm}$ in width and $4 \mathrm{~m}$ length. Each plot included 4 ridges and the plot area was about $12 \mathrm{~m}^{2}$.The experimental design was a complete randomized blocks with five replications for each treatment. The analysis of plant residue vermicompost indicated: $\mathrm{PH}=7.2, \mathrm{EC}=2.4 \mathrm{dSm}{ }^{-1}, \mathrm{~N}=1.8 \%, \mathrm{P}=$ $0.55 \%, \mathrm{~K}=1.2 \%, \mathrm{Cu}=12 \mathrm{ppm}, \mathrm{Zn}=40 \mathrm{ppm}, \mathrm{Fe}=1320 \mathrm{ppm}$, and $\mathrm{Mn}=110 \mathrm{ppm}$. The treatments consisted of plant residue vermicompost with different concentrations of rates $\left(0,1,2\right.$ and 3 ton fed $\left.{ }^{-1}\right)$ and incorporated in the top $15 \mathrm{~cm}$ layer of soil in the experimental beds before the plantation of lettuce seedlings. The recommended dose of NPK chemical fertilizers used in this experiment according to the Ministry of Agriculture, foliar spray of Spirulina platensisat rates of $\left(1\right.$ and $\left.2 \mathrm{gL}^{-1}\right)$ three sprays at 2 weeks intervals were used. Spirulina platensis was mixed with water to get the desired concentration.

The experimental treatments were as follows:

1- Control (without vermicompost)+foliar spray spirulina platensis extract $1 \mathrm{gL}^{-1}$

2- Control (without vermicompost)+foliar spray spirulina platensis extract $2 \mathrm{gL}^{-1}$

3- Vermicompost at 1 ton fed- ${ }^{1}+$ foliar spray of spirulina platensis extract $1 \mathrm{gL}^{-1}$

4- Vermicompost at 1 ton fed- ${ }^{1}+$ foliar spray of spirulina platensis extract $2 \mathrm{gL}^{-1}$

5- Vermicompost at 2 ton fed- ${ }^{1}+$ foliar spray of spirulina platensis extract $1 \mathrm{gL}^{-1}$

6- Vermicompost at 2 ton fed- ${ }^{1}+$ foliar spray of spirulina platensis extract $2 \mathrm{gL}^{-1}$

7- Vermicompost at 3 ton fed- ${ }^{1}+$ foliar spray of spirulina platensis extract $1 \mathrm{gL}^{-1}$

8- Vermicompost at 3 ton fed- ${ }^{1}+$ foliar spray of spirulina platensis extract $2 \mathrm{gL}^{-1}$ 
All agriculture practices operations other than experimental treatments necessary for growth and development as cultivation, irrigation and pest control were followed whenever it was necessary and were done according to the recommendations of Ministry of Agriculture, Egypt.

\section{Preparation of Algae Extract}

The used algae in the present study Spirulina platensis is photosynthetic and multicellular blue-green microalgae that grow in a wide range fresh, marine and brackish water (Marrez et al., 2014). The fresh algae material (One kg) was cut into small pieces and weighted. The sample was extracted using a blender. The blended material was filtered through a double-layered of muslin cloth to remove debris and designated as $100 \%$ and different used concentrations in this study were prepared by adding tap water and refrigerated between $0-4^{\circ} \mathrm{C}$ until use [15]. The source of algae fresh (Algal Biotechnology Unit, NRC, Egypt). The plants were sprayed with algae extract after 30 and 45 days from seedlings and the untreated plants(check) were sprayed with tap water. The chemical characteristics of algae were present in Table (1).

Table 1:Chemical composition of some macro- micronutrients, of Spirulina platensis fertilizer used in the experiment study

\begin{tabular}{|l|l|l|l|l|l|l|l|l|l|l|l|}
\hline \multirow{2}{*}{ Carbohydrate (\%) } & \multirow{2}{*}{ Crude protein \% } & \multicolumn{4}{|l|}{ Macronutrients (\%) } & \multicolumn{4}{|c|}{ Micronutrients (ppm) } \\
\cline { 3 - 12 } & & $\mathbf{N}$ & $\mathbf{P}$ & $\mathbf{K}$ & $\mathbf{M g}$ & $\mathbf{C a}$ & $\mathbf{F e}$ & $\mathbf{Z n}$ & $\mathbf{M n}$ & $\mathbf{C u}$ \\
\hline 22.7 & 48.13 & 6.8 & 0.67 & 1.72 & 0.01 & 0.33 & 1107 & 28 & 56 & 5 \\
\hline
\end{tabular}

\section{Date Recorded:}

Studied Characters: after 75 days from transplanting, at full plants were chosen from each treatment to determine the studied characters:

\section{Morphological Characters:}

Plant height $(\mathrm{cm})$, fresh and dry matter of leaves $\mathrm{g}_{\text {plant }}{ }^{-1}$, number of leaves plant ${ }^{-1}$, fresh and dry matter of roots $\mathrm{g}$ plant ${ }^{-1}$, leaf areamm $^{2}$, yield/plots $\mathrm{kg}$ and total yield ton fed ${ }^{-1}$.

\section{Chemical constituents:}

- $\quad$ The percentage of N, P, K in leaves were determined according to the methods in (Cottenie $\boldsymbol{e t}$ al.,1982). Zinc, manganese, iron and copper content were determined using atomic absorption spectrophotometer as described by Cottenie et al., [16].

- Chlorophyll a (Chl. a), chlorophyll b (Chl. b), and carotenoids (Carot.) content were estimated according to the method described by Lichtenthaler [17].

- $\quad$-Total carbohydrate percentage in leaves (\%): dry matter of each treatment was used for determination total carbohydrates\% were colorimetrically determined using phenol-sulphoric acid reagent method as outlined by Dubois et al., [18].

- $\quad$-Vitamin C was estimated in cauliflower heads according to the method reported in A.O.A.C. [19].

\section{Statistical analysis:}

All data obtained during each season were subjected to analysis of variance according to Snedecor and Cochran [20]. The least significant differences (LSD) at $\mathrm{P}=0.05$ level was used to verify the difference between means of the treatments.

\section{RESULTS AND DISCUSSION}

\section{Growth parameters:}

In present work, the impact of vermicompost fertilizer and foliar spray of spirulina platensis extract on growth parameters and productivity of lettuce plants based on the information in Table 1. Results indicated that addition of vermicompost fertilizer at rates of $\left(1,2\right.$ and 3 ton fed $\left.^{-1}\right)$, and foliar spray of spirulina platensis extract (1and $\left.2 \mathrm{gL}^{-1}\right)$ within all tested treatments resulted had significant increases promoted growth characters and yield than the characteristics of the control [21]. The improvements in plant growth could be due partially to large increases in soil microbial biomass after vermicompost applications, leading to the production of hormones in the vermicompost acting as plant-growth regulators independent of nutrient supply. Obtained results agreed with those of Prabha et al., [22] Tahmineh, and Parviz, [23]. In addition, application of vermicompost at 2 ton fed- ${ }^{1}+$ foliar spray of spirulina platensis extract $2 \mathrm{gL}^{-1}$ followed by vermicompost at 3 ton fed- ${ }^{1}+$ foliar spray of spirulina platensis extract $2 \mathrm{gL}^{-1}$ significantly increased most parameters under study as compared to other treatments and control. Whilst, the lowest increase most parameters was obtained from vermicompost at rate of 1 ton $\mathrm{fed}^{-1}+$ foliar spray of spirulina platensis extract $1 \mathrm{gL}^{-1}$, while the reverse was in leaf area and dry matter of roots.

Data presented in Table (2) data also, showed that using of spirulina platensis extracts foliar spray at a rate of 1 and $2 \mathrm{gL} \mathrm{can} \mathrm{be}^{-1}$ useful in increasing growth parameters and yield over the control (tap water spray) [24].

Vernieri et al., [24] showed that the application of the biostimulant of plant extracts had a positive effect on plant growth in lettuce and spinach and improved the root/shoot ratios. In lettuce, the biostimulant strongly stimulated the root growth and showed an increase in the leaf area. As compared between with application vermicompost fertilizer and foliar spray of spirulina platensis extract at a rates of $\left(1\right.$ and $\left.2 \mathrm{gL}^{-1}\right)$, data demonstrated that application a foliar spray of spirulina platensis extract at rate of $2 \mathrm{gL}^{-1}$ 
gave a significant increased most growth parameter as compared with application a foliar spray of spirulina platensis extract at rate of $1 \mathrm{gL}^{-1}$.

Generally,the significant effect of the alga extract can be attributed to its impact in improving the permeability of the cell membrane and promoting plant efficiency in the absorption of nutrients such as nitrogen directly associated to the concentrat ion of leaf chlorophyll. Furthermore, algae extract can play a role in delaying the aging of leaves by reducing chlorophyll degradation by its cytokinin content. In addition, microalgae help to restore soil's natural nutrient rotation, to build soil organic matter and by supplying plants with various nutrients, hormones, which have a crucial impact on growth [25].

Table 2: Effect of different rates of vermicompost fertilizer with foliar application of spirulina platensis extract on growth parameter and yield in Lettuce plants (Average of two seasons)

\begin{tabular}{|c|c|c|c|c|c|c|c|c|c|}
\hline $\begin{array}{l}\text { Vermicompost } \\
\text { (ton } \text { fed }^{-1} \text { ) }\end{array}$ & $\begin{array}{c}\text { Spirulina } \\
\text { Extract }\left(\mathrm{gL}^{-1}\right)\end{array}$ & $\begin{array}{l}\text { F. M. of } \\
\text { leaves plant }{ }^{-1}\end{array}$ & $\begin{array}{c}\text { D. M. of } \\
\text { leaves plant }{ }^{-1}\end{array}$ & $\begin{array}{l}\text { No. of leaves } \\
\text { plant }^{-1}\end{array}$ & $\begin{array}{l}\text { Leaf } \\
\text { area } \mathrm{cm}^{2}\end{array}$ & $\begin{array}{c}\text { F. M. of } \\
\text { Rootsplant }^{-1}\end{array}$ & $\begin{array}{l}\text { D. M. of } \\
\text { Root plant }^{-1}\end{array}$ & $\begin{array}{c}\text { yield } \\
\text { /plot kg }\end{array}$ & $\begin{array}{c}\text { Yield ton } \\
\text { fed }^{-1}\end{array}$ \\
\hline \multirow{2}{*}{0} & 1 & 291.0 & 32.88 & 33.30 & 165 & 33.33 & 4.66 & 18.46 & 4.39 \\
\hline & 2 & 330.3 & 37.33 & 34.00 & 196 & 35.33 & 4.94 & 22.80 & 4.61 \\
\hline \multirow{2}{*}{1} & 1 & 317.0 & 35.82 & 37.33 & 201 & 36.00 & 5.62 & 24.33 & 5.10 \\
\hline & 2 & 396.3 & 44.19 & 41.33 & 244 & $40 . .00$ & 6.15 & 28.76 & 5.60 \\
\hline \multirow{2}{*}{2} & 1 & 377.7 & 42.68 & 45.00 & 230 & 39.00 & 5.46 & 25.00 & 5.80 \\
\hline & 2 & 465.3 & 52.60 & 53.02 & 347 & 46.33 & 5.60 & 34.28 & 8.48 \\
\hline \multirow{2}{*}{3} & 1 & 426.1 & 44.19 & 42.04 & 335 & 40.67 & 5.04 & 28.43 & 6.90 \\
\hline & 2 & 442.3 & 48.14 & 43.06 & 357 & 44.00 & 6.48 & 31.10 & 7.45 \\
\hline \multicolumn{2}{|c|}{ LSD at 0.05} & 4.00 & 4.63 & 3.17 & 115.2 & 5.50 & 0.77 & 3.55 & 0.82 \\
\hline
\end{tabular}

\section{Chemical Composition:}

Data reported in Tables $(3 \& 4)$ showed that all treatments tended to boost $\mathrm{N}, \mathrm{P}$ and $\mathrm{K}$ concentration and uptake in leaves of lettuce mixed use of vermicompost in presence of foliar spray of spirulina platensis extract compared to control in both seasons. The increase in the chemical composition may be attributed to the constituents of vermicompost and spirulina platensis extract, which help in enhancing these characters like other bio-stimulants such as natural hormones, amino acids, vitamins and antioxidants [26], [27].

The maximum $\mathrm{N}(2.69 \%)$ and $\mathrm{P}(0.34 \%)$ content was noticed in case of application vermicompost at 3 ton fed ${ }^{-1}$ with a foliar spray of spirulina platensis extract $2 \mathrm{gL}^{-1}$. The increment of leaves nitrogen concentration ranged between $97.31 \%$ and $\mathrm{P}$ concentration ranged between $99.66 \%$. Wang et al., [28] on Chinese cabbage conducted experiments to assess the effect of increasing doses of vermicompost applications and found a significant increase in the nutritional value

In comparison to the different rates of foliar spraying of spirulina platensis, extract at the rate of 1 and $2 \mathrm{gL}^{-1}$ on $\mathrm{N}, \mathrm{P}$ and $\mathrm{K}$ content and uptake in leaves of lettuce. The pooled data in (Table 3) showed that the improve the magnitude variation of $\mathrm{N}$, $\mathrm{P}$ and $\mathrm{K}$ uptake in leaves increased with respect to the rate $2 \mathrm{gL}^{-1}$ as compared with $1 \mathrm{gL}^{-1}$ in leaves.

Potassium content in leaves increased with the spraying of spirulina platensis, extract at the rate of $2 \mathrm{gL}^{-1}$ with vermicompost at 2 ton $\mathrm{fed}^{-1}$. Whereas the lowest values were obtained with spirulina platensis, extract at the rate of one $\mathrm{gL}^{-1}$ with vermicompost at 1 ton fed $^{-1}$ respectively

Phosphorus content ranged from $0.16 \%$ and $0.34 \%$ in leaves of lettuce. The highest phosphorus content $0.34 \%$ was recorded when application vermicompost at 3 ton fed ${ }^{-1}$ with a foliar spray of spirulina platensis extract $2 \mathrm{gL}^{-1}$.A study by Bai and Marabout [29] reveals that significant increase in nitrogen, phosphorus, and potassium contents of some vegetables were determined with the application of increasing doses of vermicompost.

The application of the vermicompost to the soil and foliar spray of spirulina platensis extract increased micronutrients content (Fe, $\mathrm{Zn}, \mathrm{Mn}$ and $\mathrm{Cu} \mathrm{ppm}$ ) of leavers of lettuce plants as compared to control. Data also showed that increased Fe and Mn content with application of vermicompost at the rate of 3 ton fed-1 + foliar spray of spirulina platensis extract $2 \mathrm{gL}^{-1}(607.46 \mathrm{ppm}$ and 57.40 $\mathrm{ppm}$ ) respectively. On the other hand, Zn content increased with the application of vermicompost at the rate of 2 ton fed ${ }^{-1}+$ foliar $^{-1}$ spray of spirulina platensis extract $2 \mathrm{gL}^{-1}(37.90 \mathrm{ppm})$. Whereas $\mathrm{Cu}$ content increased with application of vermicompost at the rate of 2 ton fed-1 + foliar spray of spirulina platensis extract $1 \mathrm{gL}^{-1}(9.09 \mathrm{ppm})$.Generally, an increase in iron content results in an increase in zinc content in the plants. Moreover, the organic manures are enriched with microflora that is capable of inducing the crops to uptake the micronutrients and the synergistic action of Spirulina along with organic manures promoted the zinc levels in the plant [30]. 
Table 3: Effect of different rates of vermicompost fertilizer with foliar application of spirulina platensis extract on $\mathrm{N}$, $\mathrm{P}$, K, content in leaves and roots of lettuce plants(Average of two seasons)

\begin{tabular}{|c|c|c|c|c|c|c|c|}
\hline \multirow{3}{*}{$\begin{array}{l}\text { Vermicompost } \\
\quad\left(\text { ton fed }^{-1}\right)\end{array}$} & \multirow{3}{*}{$\begin{array}{l}\text { SpirulinaExtract } \\
\mathrm{gL}^{-1}\end{array}$} & \multicolumn{3}{|c|}{ leaves } & \multicolumn{3}{|c|}{ Roots } \\
\hline & & $\mathrm{N}$ & $\mathrm{P}$ & $\mathrm{K}$ & $\mathrm{N}$ & $\mathrm{P}$ & $\mathrm{K}$ \\
\hline & & \multicolumn{6}{|c|}{$\%$} \\
\hline \multirow{2}{*}{0} & 1 & 1.73 & 0.16 & 1.81 & 0.83 & 0.09 & 0.95 \\
\hline & 2 & 1.79 & 0.19 & 1.85 & 0.91 & 0.11 & 1.05 \\
\hline \multirow{2}{*}{1} & 1 & 1.96 & 0.23 & 1.85 & 1.13 & 0.14 & 1.22 \\
\hline & 2 & 2.09 & 0.25 & 1.95 & 1.54 & 0.16 & 1.30 \\
\hline \multirow{2}{*}{2} & 1 & 2.32 & 0.26 & 2.34 & 1.68 & 0.18 & 1.68 \\
\hline & 2 & 2.55 & 0.26 & 2.55 & 1.77 & 0.18 & 1.77 \\
\hline \multirow{2}{*}{3} & 1 & 2.41 & 0.32 & 2.20 & 1.74 & 0.20 & 1.37 \\
\hline & 2 & 2.69 & 0.34 & 2.37 & 1.82 & 0.22 & 1.39 \\
\hline \multicolumn{2}{|c|}{ LSD at 0.05} & 0.50 & 0.14 & 0.69 & 0.30 & 0.11 & 0.60 \\
\hline
\end{tabular}

Table 4: Effect of different rates of vermicompost fertilizer with foliar application of spirulina platensis extract on Fe, Zn, Mn and $\mathrm{Cu}$ content in leaves and roots of lettuce plants (Average of two seasons)

\begin{tabular}{|c|c|c|c|c|c|c|c|c|c|}
\hline \multirow{3}{*}{$\begin{array}{l}\text { Vermicompost } \\
\quad\left(\text { ton fed }{ }^{-1}\right)\end{array}$} & \multirow{3}{*}{$\begin{array}{c}\text { SpirulinaExtract } \\
\left(\mathrm{gL}^{-1}\right)\end{array}$} & \multicolumn{4}{|c|}{ leaves } & \multicolumn{4}{|c|}{ Roots } \\
\hline & & $\mathrm{Fe}$ & $\mathrm{Mn}$ & $\mathrm{Zn}$ & $\mathrm{Cu}$ & $\mathrm{Fe}$ & $\mathrm{Mn}$ & $\mathrm{Zn}$ & $\mathrm{Cu}$ \\
\hline & & \multicolumn{8}{|c|}{$\mathrm{ppm}$} \\
\hline \multirow{2}{*}{0} & 1 & 286.3 & 33.97 & 25.10 & 9.23 & 74.12 & 15.90 & 8.23 & 4.30 \\
\hline & 2 & 320.3 & 39.63 & 25.50 & 8.04 & 89.35 & 18.00 & 10.55 & 3.77 \\
\hline \multirow{2}{*}{1} & 1 & 344.9 & 45.13 & 28.83 & 8.68 & 101.5 & 22.10 & 11.70 & 2.02 \\
\hline & 2 & 373.1 & 45.73 & 29.97 & 6.40 & 122.64 & 22.5 & 12.36 & 1.90 \\
\hline \multirow{2}{*}{2} & 1 & 401.1 & 47.77 & 36.40 & 9.09 & 156.38 & 25.42 & 15.00 & 4.03 \\
\hline & 2 & 441.7 & 49.67 & 37.90 & 7.39 & 174.30 & 25.90 & 15.55 & 3.80 \\
\hline \multirow{2}{*}{3} & 1 & 526.0 & 62.50 & 30.50 & 6.50 & 188.90 & 27.11 & 13.41 & 2.51 \\
\hline & 2 & 607.4 & 81.40 & 33.97 & 6.08 & 201.3 & 27.86 & 12.00 & 2.33 \\
\hline \multicolumn{2}{|c|}{ LSD at 0.05} & 115.3 & 18.30 & 6.96 & 1.87 & 96.2 & 1.90 & 2.10 & 0.60 \\
\hline
\end{tabular}

The data described in Table (5) showed that the use of vermicompost with foliar spray of spirulina platensis extract on photosynthetic pigment and carbohydrates (\%) in leaves of lettuce plants improved the content of chlorophyll a, chlorophyll b, carotenoid and Vitamin C to all prior treatments compared to control plant [31]. Moreover, it is quite clear from such data in Table 4 showed that the maximum level content of chlorophyll a, chlorophyll $\mathrm{b}$, carotenoid and total pigments were responded to the increase of foliar-applied spirulina platensis, extract at rate of $2 \mathrm{gL}^{-1}$ with vermicompost fertilizer at the rate of 3 ton fed ${ }^{-1}$. Average of increase were $88.81 \%$ in chlorophyll a, $96.24 \%$, in chlorophyll b, $96.41 \%$, in carotenoid, $81.46 \%$ in total pigmentsand $13.3 \%$ in vitamin $\mathrm{C}$ as compared to control. This finding may be due to algae extract containing cytokines that cause physiological activity and boost complete chlorophyll in crops, reflecting the photosynthesis activity and the synthesized materials which will positively reflect on the growth characteristics [23]. In addition, data in Table (5) showed that decreasing vermicompost fertilizer and foliar spray of spirulina platensis extract reduced total carbohydrate content \%in leaves. Indicating that treatments changed the source-sink relationship in the lettuces. The relocation of fixed carbon (as reduced sugars) to the root system and its subsequent incorporation into structural macromolecules such as proteins to meet the demands of fast plant growth. These result maybe provide a partial explanation for reduced in total carbohydrate content in lettuce leaves. Canellas et al., [32] found that increased variability in invertase activity stimulation among plants treated with different humic substances. This enzyme is associated with sugar metabolism, and its activity increased in comparison with control plants not treated with humic substances.

Table 5: Effect of different rates of vermicompost fertilizer with foliar application of spirulina platensis extract on photosynthesis pigment, and Vitamin C (mg/100gm F. W) and total carbohydrate \% in fresh leaves of lettuce plants(Average of two seasons)

\begin{tabular}{|c|c|c|c|c|c|c|c|}
\hline \multirow{2}{*}{$\begin{array}{l}\text { Vermicompost } \\
\quad\left(\text { ton } \text { fed }^{-1}\right)\end{array}$} & \multirow{2}{*}{$\begin{array}{l}\text { SpirulinaExtract } \\
\qquad\left(\mathrm{g} \mathrm{L}^{-1}\right)\end{array}$} & $\begin{array}{c}\text { chlorophyll } \\
\mathrm{a} \\
\end{array}$ & $\begin{array}{c}\text { chlorophyll } \\
\text { b } \\
\end{array}$ & Carotenoids & \multirow{2}{*}{$\begin{array}{c}\text { Total } \\
\text { pigment }\end{array}$} & \multirow{2}{*}{$\begin{array}{c}\text { VitaminC } \\
\text { (mg/100gmF.W.) }\end{array}$} & \multirow{2}{*}{$\begin{array}{c}\text { Carbohydrates } \\
(\%)\end{array}$} \\
\hline & & \multicolumn{3}{|c|}{$(\mu \mathrm{g} / \mathrm{g} F W)$} & & & \\
\hline \multirow{2}{*}{0} & 1 & 7.54 & 2.58 & 2.67 & 12.79 & 54.46 & 3.02 \\
\hline & 2 & 8.60 & 2.96 & 2.94 & 14.5 & 59.40 & 3.11 \\
\hline \multirow{2}{*}{1} & 1 & 9.47 & 3.20 & 3.39 & 16.06 & 58.67 & 1.26 \\
\hline & 2 & 10.03 & 3.43 & 3.63 & 17.09 & 60.04 & 1.50 \\
\hline \multirow{2}{*}{2} & 1 & 9.91 & 3.42 & 3.54 & 16.87 & 74.43 & 2.2 \\
\hline & 2 & 10.56 & 3.66 & 3.83 & 18.05 & 73.20 & 2.55 \\
\hline \multirow{2}{*}{3} & 1 & 10.0 & 3.56 & 3.82 & 17.38 & 83.45 & 2.40 \\
\hline & 2 & 11.19 & 3.76 & 3.59 & 18.54 & 86.70 & 2.80 \\
\hline \multicolumn{2}{|c|}{ LSD at 0.05} & 1.20 & 0.95 & 0.95 & 1.40 & 8.44 & 0.62 \\
\hline
\end{tabular}




\section{CONCLUSION}

The experimental result clearly demonstrated that using vermicompost and biofertilizers have significant contribution to the growth and productivity of lettuce yield in sandy soil. Also, reduce the $\mathrm{N}$ fertilizer which good results for human health and reduce the soil pollution without reducing the yielding. On the long-term effects, using compost could alternatively help to save the mineral fertilizer costs for many cycles of production

\section{REFERENCES}

[1] Ibrahim, R. and Zuki, W.A.M. 2013. The Physico-Chemical Properties Of Lettuce (LactucaSativa'Grand Rapid') Grown Under Different Planting Methods. Acta Hort. (ISHS) 1012:201-206.

[2] FAO (2008). La agricultura organicaen la FAO. In: http://www.fao.org/organicag /frame1-s.htm; consulted: August, 2011.

[3] Leogrande, R., Lopedota, O., Fiore, A., Vitti, C.,Ventrella, D., Montemurro, F.( 2013). Previous crops and organic fertilizers in lettuce: Effects on yield and soilproperties. Journal of Plant Nutrition 36: 1945-1962

[4] Irajkhazaei; R. S., Abdolkarim K. and Seyed M. M. (2013). Improvement of lettuce growth and yield with spacing, mulching and organic fertilizer. Intl J Agri Crop Sci. Vol., 6 (16), 1137-1143.

[5] Hossain M.B. and Ryu K.S (2017) effects of organic and inorganic fertilizers on lettuce (lactuca sativa 1.) and soil properties.SAARC J. Agri., 15(2): 93-102.

[6] Moreira, M.A., Santos, C.A.P., Lucas, A.A.T., Bianchini, F.G., de Souza, I.M., and Viegas,P.R.A. (2014). Lettuce production according to different sources of organic matter and soil cover. Agricultural Sciences, 5: 99-105.

[7] Adhikary, S., (2012) Vermicompost, the story of organic gold: A review. Agricultural Sciences, 3(7),.905-917.

[8] Pallabi Mishra and Debiprasad Dash (2014), Rejuvenation of bio-fertilizer for sustainable agriculture and economic development. Consilience: The Journal of Sustainable Development, 11(1), 41-61.

[9] Shalaby, T.A., H. El Ramady. (2014). Effect of foliarapplication of bio-stimulants on growth, yieldcomponents and storability of garlic (Allium sativumL.). Aust. J. Crop. Sci. 8:271-275

[10] Manrich, A.; Mermejo, B. C.; Morais, J. C.; Oliveira, J. E.; Mattoso, L. H. C.; Martins, M.A. 2014 Determinação Da ComposiçãoQuímica Da Spirulina Platensis. In. Workshop De NanotecnologiaAplicadaAoAgronegócio, 8., 2014, SãoCarlos. Anais... São Carlos: EmbrapaInstrumentação,.p.116-120

[11]Faheed, F.A.; Fattah, A.A.-E. (2008) Effect of Chlorella vulgaris as bio-fertilizer on growth parameters and metabolic aspects of lettuce plant, J. Agric. Soc. Sci. 4 165-169.

[12] Shy C.Wuang. ; Mar C. K.; Pei Q. D. C. and Yanpei D. L. (2016) Use of Spirulina biomass produced from treatment of aquaculture wastewater as agricultural fertilizers. Algal Research 15 (2016) 59-64.

[13] Klute A. (1986). Methods of Soil Analysis, Part 1, Physical and Mineralogical Methods 2nd edition.American Society of Agronomy, Madison, Wisconsin, USA.

[14] Page AI, Miler RH and Keeny DR. (1982). Methods of Soil Analysis part II. Chemical and Microbiological Methods.2nded. Amer. Soc. Agron., Madison, Wisconsin, USA.

[15]Pise, N. M. and A. B. Sabale, (2010). Effect of seaweed concentrates on the growth and biochemical constituents of Trigonellafoenum- graecumL. J. Phytology, 2 (4): 50-56.

[16] Cottenie, A., M. Verloo, L. Kiekens, G. Velghe and R. Camerlynck, (1982).Chemical Analysis of Plant and Soil. PP. $100-$ 129. Laboratory of Analytical and Agrochemistry, State Univ. Ghent. Belgium.

[17] Lichtenthaler H.K. (1987) Chlorophylls and carotenoids: pigments of photosynthetic biomembranes. Methods in Enzymology 149:351-382.

[18] Dubois MF, Gilles KA, Hamiton JK, Robers PA and Smith F.(1956). Colorimetric method for determination of sugars and related substances.Anal. Chem., 28: 350-354

[19] A.O.A.C. (2000).Association of Official Analytical Chemists.17th ED. Of A.O.A.C. international Published by AOAC international Maryland, USA, 1250pp

[20] Snedecor GW and Cochran WG.(1980). Statistical Methods.7th ed., Iowa State Univ. Press, Ames, Iowa, USA.

[21] Ahmed YM,andShalaby EA (2012) Effect of different seaweed extracts and compost on vegetative growth, yield and fruit quality of cucumber. J HorticSci Ornament Plants 4(3):235-240

[22] Prabha ML, Jayraay IA, Jayraay R, Rao DS (2007).Effect of vermicompost on growth parameters of selected vegetable and medicinal plants. Asian Journal of microbiology, Biotechnology and Environmental Sciences, 9(2), 321-326.

[23] Tahmineh, B. and Parviz, S. (2013). Effect of vermicompost on Tomato (Lycopersicum esculentum) Fruits. International Journal of Agronomy and Plant Production. Vol., $4: 2965-2971$.

[24] Vernieri, P., Malorgio, F.andTognoni, F. (2002): Use of biostimulants in production of vegetable seedlings. Colture-Protette, 31: 75-79.

[25] Débora Samara Oliveira E Silva; RaileneHérica Carlos Rocha; Jackson Da Silva Nóbrega; George Alves Dias; José Franciraldo De Lima; Wellinghton Alves Guedes(2017) Post-harvest quality of lettuce cv. Elba in relation to Spirulina platensis foliar applications.Científica, Jaboticabal, v.45, n.2, p.162-168

[26] AlperDurak; ÖzlemAltuntaş; İbrahim Kutalmışutsal, RabiaIşık and FıratEgeKaraat(2017). The Effects of Vermicompost on Yield and Some Growth Parameters of Lettuce Turkish Journal of Agriculture - Food Science and Technology, 5(12): 15661570. 
[27] Sevinç A.; Funda E. A.; Yusuf S. E. and Aydın A. (2018) Effect of Vermicompost on the Growth and Yield of Lettuce Plant (Lactuca sativa L. var. crispa. International Journal of Plant \& Soil Science 21(1): 1-5.

[28] Wang, D., Q. Shi, X. Wang, M. Wei, J. Hu, J. Liu, and F. Yang,( 2010). Influence of cow manure vermicompost on the growth, metabolite contents, and antioxidant activities of Chinese cabbage (Brassica campestris ssp. chinensis). BiolFertil Soils (2010) 46:689-696.

[29] Bai BA, and MalakoutMJ(2007). The Effect of different organic manures on some yield and yield quality parameters in onion. Iran Soil and Water Sci. J.;21(1):43-53.

[30] Kalpana, P., Saibramari, G. and Anitha, L. (2014) Biofortification of AmaranthusgangeticusUsingSpirulina platensis as Microbial Inoculant to Enhance Iron Levels.IMPACT: International Journal of Research in Applied, Natural and Social Sciences (IMPACT: IJRANSS), 2, 103-110.

[31] Koudela, M., Petrríková, K., 2008: Nutrients content and yield in selected cultivars of leaf lettuce (Lactuca sativa L. var. crispa).Horticultural Science 35, 99-106

[32] Canellas LP, Martinez-Balmori D, Médici LO, Aguiar NO, Campostrini E, Rosa RCC, Façanha AR, Olivares FL (2013) A combination of humic substances and Herba spirillum seropedicae inoculation enhances the growth of maize (Zea mays L.). Plant Soil 366:119-132. 